\title{
HOW AGRICULTURE AFFECTS LICHEN VEGETATION IN CENTRAL SWITZERLAND
}

\author{
Engelbert RUOSS $\star$
}

\begin{abstract}
The results from several floristic and bioindication projects in Central Switzerland (1986-1998), focusing on the effects of agriculture, particularly from nitrogen and agrochemical emissions, are summarized. The abundance of nutrienttolerant lichen species and the decreased occurrence of nitrophytic lichens are both correlated with agricultural land use and high atmospheric deposition. The impact could be demonstrated not only by the distribution patterns of nutrient-tolerant species, but also by the high $\mathrm{N}$ content of lichens such as Physcia caesia. Positive growth response of Cetraria islandica to application of mineral nutrients and increased $\mathrm{CO}_{2}$ in open-top chambers at high altitudes was also observed. The methods and a survey of the results from studies conducted within the framework of the lichen research programme of the Natural History Museum of Lucerne are presented here. A discussion of the issues shows the need for further studies concerning the influence of introduced nutrients on the biodiversity of lichens.
\end{abstract}

C) 1999 The British Lichen Society

\section{Introduction}

Studies conducted in Central Switzerland from 1986 to 1991 in agricultural and remote prealpine areas showed lichen distribution to be closely correlated with high nutrient emissions and with atmospheric deposition (Ruoss \& Clerc 1987; Ruoss 1992; Ruoss et al. 1992). The question arose as to what extent agriculture affected lichen vegetation. Therefore additional projects by the Natural History Museum of Lucerne (NML) lichen research programme dealing with the impact of agriculture were carried out. The lichen mapping project in the canton of Lucerne included the characterization of landscapes in Central Switzerland and the monitoring of nitrogen emissions using lichens as indicators (Ruoss 1991, 1992; Müller et al. 1993). The nitrophytic lichen vegetation in rural areas is not only a result of high input of nutrients through farming, but also of considerable atmospheric nitrogen $(\mathrm{N})$ deposition. In an additional study, the effects of atmospheric deposition upon bog vegetation including lichens and bryophytes were studied in the prealpine area (Dussex \& Held 1990).

Comparative lichen mapping studies showed similar effects in other parts of Switzerland such as the Lake Zürich region (Vonarburg et al. 1990), the agglomeration of St. Gallen (Meile 1993) and the southern prealpine area in Tessin of southern Switzerland (Walter 1997). Microclimatic studies connected with the water balance of lichens showed that lichen colonization depends strongly on the interaction between microclimatic factors and ^Natur-Museum Luzern, Kasernenplatz 6, CH-6003 Luzern, Switzerland. 
immission (Vonarburg 1993). In alpine grasslands, the factors limiting growth are mainly nutrients, which play an important role in promoting or inhibiting growth (Ineichen 1994).

The air pollution programmes conducted by the Department of Environment of Lucerne (Amt für Umweltschutz 1993) and the Federal Office of Environment, Forests and Landscape (FOEFL 1996) show considerable N deposition in the study area. The aim of this paper is to summarize the different ways agriculture affects lichens, based on results and observations obtained from the various studies of the NML lichen research programme. Possible issues for follow-up studies and for using lichens in large-scale biomonitoring experiments are also discussed.

\section{Survey of methods}

The study area is situated in the northern and southern prealpine area, which includes the cantons Lucerne, Zug, Schwyz, Obwalden, Zürich, St. Gallen and Tessin. Below is a summary of the principal methods used. More specific methods are outlined in appropriate references.

\section{Mapping studies}

For the studies within the NML lichen research programme, comparable mapping methods were used. The epiphytic lichen flora on the following isolated deciduous trees were studied: Quercus robur, Fraxinus excelsior, fuglans regia, Tilia cordata, T. platyphyllos, Aesculus hippocastanum, and Acer pseudoplatanus. Plots ranging from one to two metres in height were registered in the following locations: canton Lucerne 368 plots (Ruoss 1992) and 323 plots (Graf 1998), Lake Zürich 131 plots (Vonarburg et al. 1990), canton Tessin 211 plots (Walter 1997), canton St. Gallen 160 plots (Meile 1993). Frequency of individual lichen species, total cover and species number were calculated. The phytosociological methods of Braun-Blanquet (1928) and Wirth (1972) were used, with indication values (especially $N$-values) being interpreted according to Wirth (1991). The influence of nutrients is defined by the $\mathrm{N}$-value, which is taken to represent different amounts of mineral supply, using the presence or absence of appropriate lichen species on a scale of 1-9. Nomenclature follows Wirth (1995).

A lichen diversity index $\left(\mathrm{LI}=\mathrm{c} \times \frac{\mathrm{s}}{\mathrm{an}}\right.$; $\mathrm{c}=$ total cover, $0-100 \%$; $\mathrm{s}=$ species number, range $1-34$ ) was calculated to describe quantitatively the diversity and abundance of lichens and the natural potential of habitats. In order to observe changes in lichen diversity, the optimum and the range of LI for lichen colonization from different regional types had to be defined (Fig. 1). Actual colonization of lichens on trees in an area could then be compared to this 'hypothetical 'optimum of region types.

\section{Measurements of atmospheric deposition}

In the study from 1988-1989 the atmospheric $\mathrm{N}$ deposition in the prealpine area was measured in four bogs and correlated with studies of vegetation in 13 bogs (Dussex \& Held 1990). Ninety permanent plots $\left(1 \mathrm{~m}^{2}\right)$ were established in bogs for the purpose of follow-up studies. Field methods included measurements with passive $\mathrm{NO}_{2}$ collectors and precipitation collection with bulk samplers. Laboratory analyses included: acidity by $\mathrm{pH}$ electrode, ammonium by flow injection analysis, cations by atomic absorption spectrophotometry, and anions by ion chromatography.

\section{Nitrogen content of lichens}

The lichens on a barn roof were studied in 1988 near Lucerne in an area subject to intensive agriculture. Unwashed samples of Physcia caesia from the barn roof and from control sites were analysed for their nitrogen content by the method of Kjeldahl (Ugrinosits 1980) and the nitrate content with high pressure liquid chromatography (HPLC). 


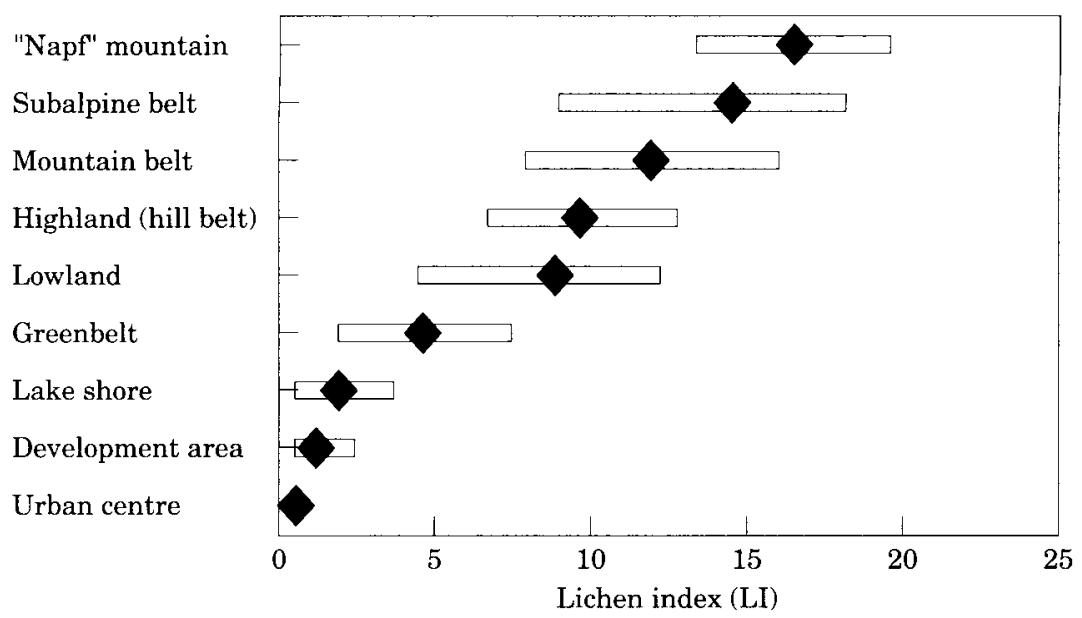

FIG. 1. Lichen index (average and standard deviation) of different landscapes in the canton of Lucerne. Intensive agriculture is located in lowland/greenbelt regions. $\bullet=$ Average LI; $n=368$.

\section{Growth response of alpine lichens}

The growth response of Cetraria islandica and Stereocaulon alpinum exposed to controlled concentrations of carbon dioxide $\left(\left[\mathrm{CO}_{2}\right]\right)$ in open-top chambers (OTCs) was studied between July 1992 and September 1994. Located in alpine grasslands dominated by Carex curvula, the field station with a total of 48 plots in the Swiss Central Alps at Bidmeren at an altitude of $2470 \mathrm{~m}$ was part of a larger ecosystem study (Körner et al. 1997). The plots were assigned to three treatments (16 plots per treatment): OTCs with doubled $\left[\mathrm{CO}_{2}\right]( \pm 680 \mathrm{ppm})$, OTCs with ambient $\left[\mathrm{CO}_{2}\right]$ and an unenclosed control group. To simulate the effect of lowland nitrogen deposition rate, 12 plots were treated with mineral nutrients. Growth measurements included four lichen samples per plot weighed before and after exposure during the study period.

\section{Synopsis of Results}

\section{Mapping as a tool to study the effects of agriculture upon lichens}

The average lichen index (LI, Fig. 1) on the Swiss Plateau (altitude $450-900 \mathrm{~m}$ ) clearly decreased from regions with less disturbed landscapes (LI: $8 \cdot 4-12 \cdot 4$ ) to regions with intensive agriculture (LI: $4 \cdot 3-8 \cdot 6$ ) and to urban areas (LI: $0 \cdot 4-4 \cdot 8$ ). In mountain and subalpine areas in the Prealps $(900-1600 \mathrm{~m})$, the average LI decreased from less intensively cultivated regions (LI: 13.9-20.5) to regions with year-round stock farming (LI: $9 \cdot 3-11 \cdot 0)$. The number of lichen species increased from agricultural areas (total 84 epiphytic species) to mountain areas (140 species): from 15-19 species to 20-27 species per tree, respectively. On the Swiss Plateau, $70 \%$ of the lichens common to this area (minimum 10\% of trees) were nitrophytic species (Xanthoria, Physcia, Phaeophyscia), whereas the remaining 30\% were anitrophytic. 'Sensitive' lichens were absent (e.g. Usnea, Bryoria, Anaptychia, Parmelia). In the prealpine area both anitrophytic and nitrophytic lichens were equally prevalent $(50 \%$ each). The gradient also correlated with climatic changes and increasing altitude. 


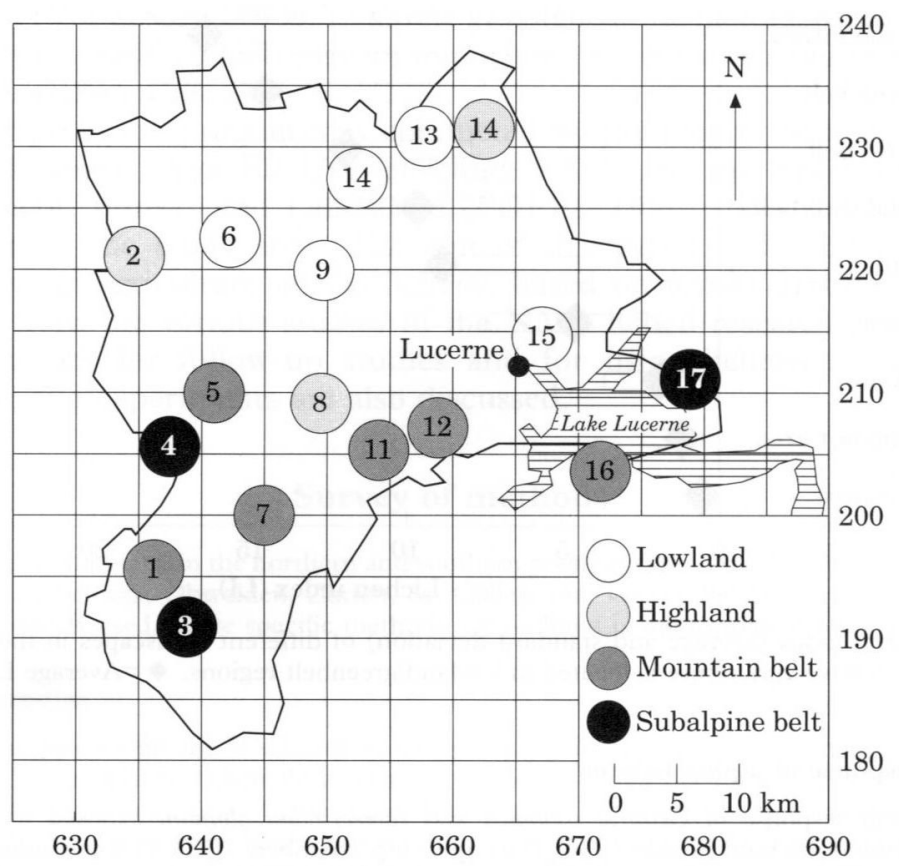

FIG. 2. Mean N-values of lichens from different regions with changing intensity of agriculture in the canton of Lucerne (see Table 1).

A high occurrence of nitrophytic lichens corresponded with the intensity of farming. In the city of Lucerne the lichen diversity in greenbelt areas with intensive agriculture (average: $\mathrm{LI}=4 \cdot 3$ ) was higher than in residential areas $(\mathrm{LI}=0 \cdot 4)$. Eutrophication, connected with ecological factors, was conducive to lichen colonization. The rich lichen flora of mountain areas contrasted considerably with the flora of agricultural areas, where few species with abundant cover (Physcia adscendens, Xanthoria candelaria, $X$. fallax group) exist and are thought to be influenced by eutrophication.

Based on the $\mathrm{N}$-values, a gradient from nitrophytes in regions with different intensity of land usage could be shown (Fig. 2, Table 1). High mean $\mathrm{N}$-values $(>4 \cdot 0)$ could be observed in both lowland and highland areas. Scattered high mean $\mathrm{N}$-values existed in mountain belt areas where intensive summer pasturing occurred. Low values were well correlated with the presence of anitrophytic lichens in the subalpine belt and the remaining mountain belt (Fig. 3).

Lichen data involving the tree species fuglans regia had to be excluded from the studies in Central Switzerland. The results from fuglans did not correlate with those from other tree species considered (Ruoss \& Keller 1988). This tree was planted mainly near farms and had lichen cover that was relatively homogeneous and consisted of nitrophytic species. Candelariella xanthostigma, Parmelia tiliacea, Physcia adscendens, Phaeophyscia orbicularis and Xanthoria parietina dominated with frequencies $>80 \%(n=16)$. 
TABLE 1. Mean N-value and altitude of different regions in the canton of Lucerne

\begin{tabular}{rlrcr}
\hline Region & & $n^{\star}$ & Mean N-value & Altitude \\
\hline 1 & & & & \\
2 & Escholzmatt & 13 & $4 \cdot 50$ & 1066 \\
3 & Zell & 19 & $4 \cdot 18$ & 669 \\
4 & Hilferen & 8 & $3 \cdot 94$ & 1246 \\
5 & Mapf & 5 & $4 \cdot 02$ & 1349 \\
6 & Schötzerg & 8 & $4 \cdot 04$ & 1056 \\
7 & Schüpfheim & 9 & $4 \cdot 21$ & 557 \\
8 & Werthenstein & 8 & $4 \cdot 11$ & 1056 \\
9 & Nottwil & 8 & $4 \cdot 27$ & 908 \\
10 & Sursee & 9 & $4 \cdot 43$ & 636 \\
11 & Schwarzenberg & 15 & $4 \cdot 42$ & 596 \\
12 & Eigental & 8 & $4 \cdot 32$ & 1016 \\
13 & Menziken & 7 & $3 \cdot 96$ & 1004 \\
14 & Müswangen & 7 & $4 \cdot 17$ & 545 \\
15 & Rotsee & 5 & $4 \cdot 40$ & 771 \\
16 & Bürgenstock & 15 & $4 \cdot 78$ & 446 \\
17 & Rigi & 33 & $3 \cdot 07$ & 1330 \\
\hline
\end{tabular}

${ }^{\star} n=$ number of plots per region.

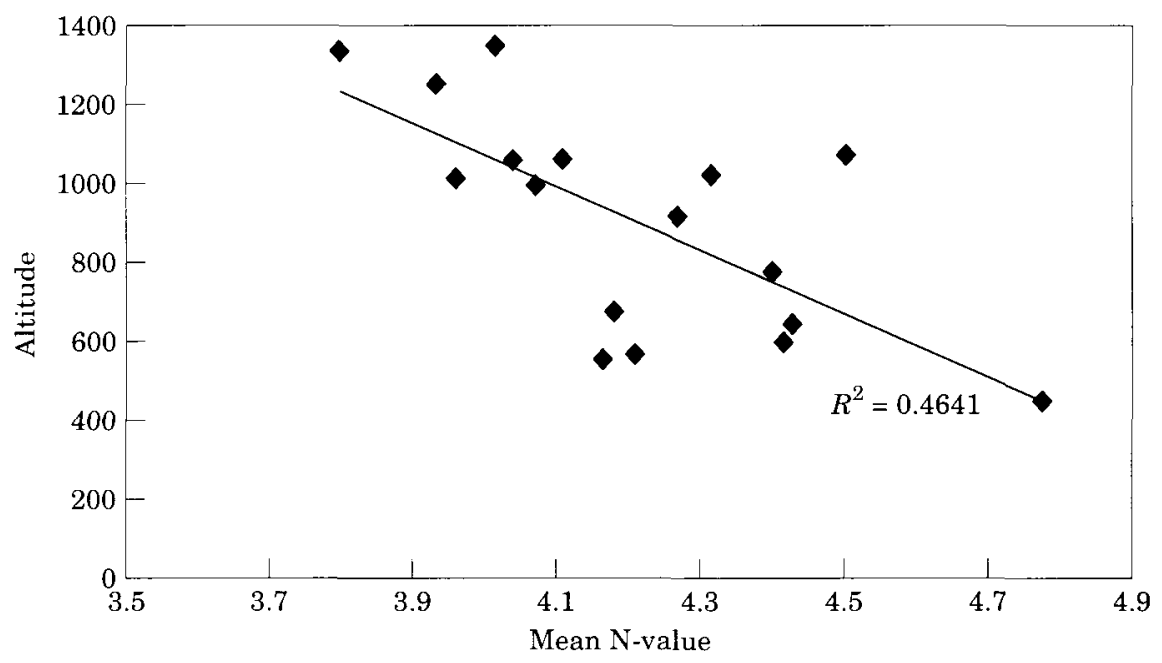

FIG. 3. Mean N-values of the different regions correlated with altitude.

In canton Tessin in southern Switzerland, fuglans was widespread in the investigation area and showed a marked difference in lichen colonization to the northern prealpine fuglans. Here it was covered with a more heterogeneous lichen flora indicating a mineral-rich substratum (Walter 1997). In addition to species prevalent in the northern prealpine region, species likewise dominating were Candelaria concolor, Lecanora allophana, L. chlarotera, X. fallax group, 
TABLE 2. Mean N-values and lichen indices of different species

\begin{tabular}{lrcc}
\hline Tree species & $n^{\star}$ & Lichen index & Mean N-value \\
\hline Populus italica \& P. tremula & 9 & $5 \cdot 63$ & $4 \cdot 95$ \\
Fuglans regia & 18 & $8 \cdot 34$ & $4 \cdot 70$ \\
Fraxinus excelsior & 52 & $9 \cdot 70$ & $4 \cdot 38$ \\
Aesculus hippocastanum & 114 & $1 \cdot 50$ & $4 \cdot 34$ \\
Quercus robur & 29 & $9 \cdot 10$ & $4 \cdot 17$ \\
Acer pseudoplatanus & 93 & $12 \cdot 77$ & $4 \cdot 03$ \\
Tilia cordata \& T. platyphyllos & 55 & $7 \cdot 20$ & $3 \cdot 86$ \\
Betula pendula & 7 & $7 \cdot 56$ & $3 \cdot 67$ \\
Fagus sylvatica & 7 & $5 \cdot 74$ & $3 \cdot 44$ \\
Picea abies & 7 & $5 \cdot 43$ & $2 \cdot 38$ \\
Abies alba & 7 & $7 \cdot 76$ & $2 \cdot 29$ \\
\hline
\end{tabular}

${ }^{\star} n=$ number of plots.

Physconia distorta, Parmelia exasperatula, P. subrudecta and Physcia aipolia. The results were comparable to those of other tree species considered, with the LI ranging from 0.02 (town centre of Chiasso, $230 \mathrm{~m}$ a.s.l.) to 20.7 (Monte San Giorgio, $1110 \mathrm{~m}$ a.s.1.). The LI values on Fuglans in rural areas in southern Switzerland (LI: $4 \cdot 5-7$ ) corresponded to those in rural areas of the northern Prealps. Fuglans regia was therefore regarded as a suitable tree for lichen bioindication in southern Switzerland.

With regard to the mean $\mathrm{N}$-values of the lichens from each tree species, a clear difference between trees with anitrophytic species (i.e. Picea abies or Abies $a l b a$ ) and those with lichens showing a high mean N-value (i.e. Populus species and $\mathcal{F}$. regia) could be seen (Table 2 ).

Locally, the effects of eutrophication and $\mathrm{pH}$ changes could be observed along the city of Lucerne's narrow roads, railways and trails (dog walks). There, Xanthoria parietina and even Parmelia acetabulum grew well (Fig. 4-bottom; tree nos 180-210), whereas other common lichen species were absent. Similar observations were made in other regions (Vonarburg et al. 1990). Well-developed $X$. parietina could also be found near Allmend (Fig. 4-top; tree nos 80-100), an area known for its sportsfields, where intense fertilization occurs.

\section{Effects of nitrogen deposition upon bog vegetation}

Measurements in the Mt. Rigi area showed a high deposition rate of ammonium with rain following periods of dry weather (Ruoss et al. 1992). Instead of acidification, neutralization of precipitation on Mt. Rigi was observed ( $\mathrm{pH}$ of rain $>5$ ). Annual averages of $\mathrm{pH}$ in the prealpine area were $4 \cdot 8-5 \cdot 0$. The ' high' $\mathrm{pH}$ was interpreted as neutralization by high ammonium concentration derived from $\mathrm{NH}_{3}$ emitted by the intensive agriculture in this region, an area of $5000 \mathrm{~km}^{2}$ with 440000 pigs $(22.7 \%$ Swiss stock) and 170000 cattle $(9 \cdot 2 \%$ Swiss stock) in 1993.

Wet $\mathrm{N}$ depositions of $11.6 \mathrm{~kg} \mathrm{ha}^{-1}$ year $^{-1}$ in remote prealpine areas and $17 \cdot 8 \mathrm{~kg} \mathrm{ha}{ }^{-1}$ year $^{-1}$ in lowland areas were regarded as only a fraction of the total $\mathrm{N}$ input of 30 to $60 \mathrm{~kg} \mathrm{ha}^{-1}$ year $^{-1}$. Between $65 \%$ and $83 \%$ of the total 


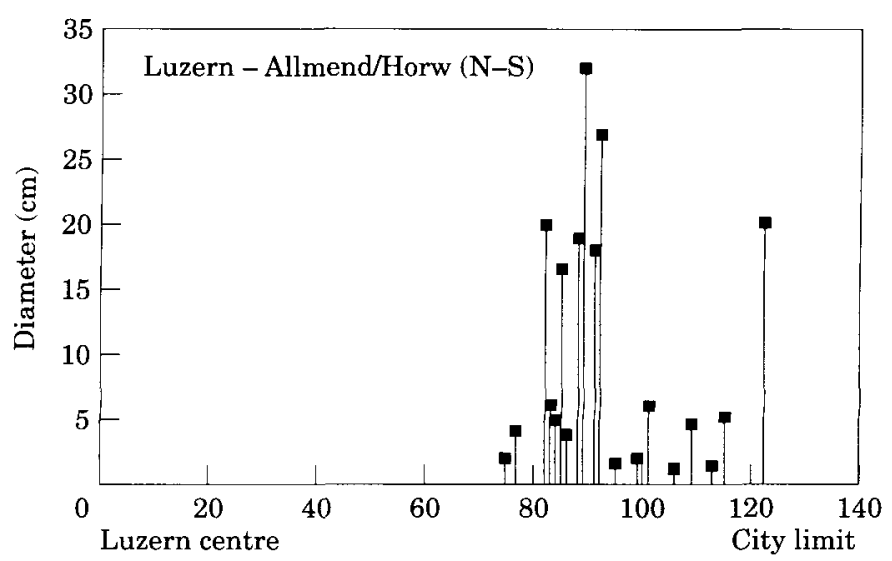

Number of tree

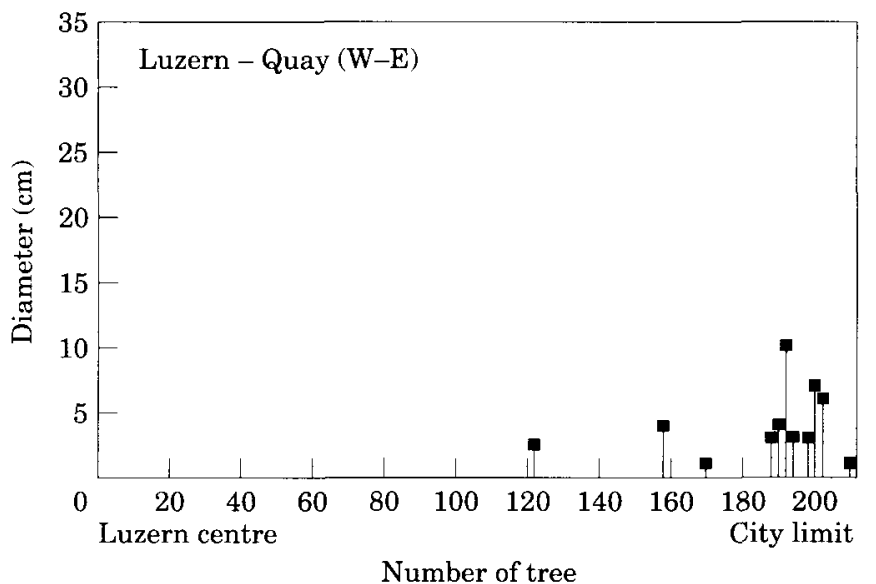

FIG. 4. Diameter of Xanthoria parietina colonies on Aesculus hippocastanum along two gradients from the centre of Lucerne to the city limit. The occurrence of well-developed Xanthoria is connected with high nutrient input. Each tree was assigned an identification number.

annual $\mathrm{N}$ deposition occurred during the growing season (Table 3). Other ions such as chloride, calcium, magnesium, sodium, potassium and phosphate occurred in trace amounts. The ratio of ammonium to nitrate (2:1) was considered important for bog vegetation, especially for Sphagnum. Between 1974 and 1989 the vegetation cover within a permanent plot in a bog changed considerably: Sphagnum species decreased from 70 to $10 \%$, bryophytes increased from 10 to $75 \%$, shrubs increased from 15 to $45 \%$. Lichens were not competitive in the prealpine bogs, and therefore they became rare in the study area.

A 1994 follow-up study verified the impact of cultivation upon bogs (Bründler Rodriguez 1997). Left alone, primary bogs showed stability in plant cover. Major changes were observable only in the cultivated secondary areas. 
TABLE 3. Nitrogen wet deposition $\left(\mathrm{kg} \mathrm{ha}^{-1}\right.$ year $\left.{ }^{-1}\right)$ during growing season, $\mathrm{NO}_{2}$ calculated from average $\mathrm{NO}_{2}$ concentration and average deposition velocity for grassland $\left(0.5 \mathrm{~cm} \mathrm{~s}^{-1}\right)$, according to Dussex E Held (1990)

\begin{tabular}{lccccccc}
\hline Locality & Altitude & $\mathrm{NO}_{3}-\mathrm{N}$ & $\mathrm{NH}_{4}-\mathrm{N}$ & $\mathrm{NO}_{2}-\mathrm{N}$ & Total N & $\begin{array}{c}\text { Total N per } \\
\text { growing season }\end{array}$ \\
\hline Salwideli & $1370 \mathrm{~m}$ & $4 \cdot 2$ & $7 \cdot 4$ & $0 \cdot 2$ & $11 \cdot 8$ & $9 \cdot 8$ & $83 \%$ \\
Tällenmoos & $850 \mathrm{~m}$ & $4 \cdot 7$ & $7 \cdot 7$ & $0 \cdot 4$ & $12 \cdot 8$ & $8 \cdot 3$ & $65 \%$ \\
Lucerne town & $435 \mathrm{~m}$ & 6.5 & $10 \cdot 0$ & $3 \cdot 2$ & $19 \cdot 7$ & 14.6 & $69 \%$ \\
Eigenried & $990 \mathrm{~m}$ & $6 \cdot 8$ & $11 \cdot 0$ & - & $17 \cdot 8$ & $12 \cdot 2$ & $74 \%$ \\
Breitried & $890 \mathrm{~m}$ & 6.5 & $10 \cdot 9$ & $0 \cdot 4$ & $17 \cdot 8$ & $13 \cdot 1$ & $74 \%$ \\
\hline
\end{tabular}

^Salwideli and Tällenmoos: moorlands c. $40 \mathrm{~km}$ west of Lucerne; Eigenried and Breitried: moorlands $c .50 \mathrm{~km}$ south-east of Lucerne.

\section{Lichen monitoring of nitrogen emissions}

On a barn roof, near intensive emission of ammonia, a dense vegetation with the following nutrient-tolerant lichen species could be observed: Candelaria concolor, Lecanora muralis, Physcia caesia, Phaeophyscia sciastra, P. orbicularis, $X$. parietina. Samples of Physcia caesia contained $89-119 \mathrm{mg} \mathrm{kg}^{-1}$ nitrate and $4 \cdot 2-4 \cdot 4 \%$ total $\mathrm{N}$; control samples $41-48 \mathrm{mg} \mathrm{kg}^{-1}$ nitrate and $1 \cdot 7-1 \cdot 8 \%$ total $\mathrm{N}$ (Ruoss et al. 1992). Lichens near emission sources seemed to have a higher nitrogen and nitrate uptake. Physcia caesia was considered a widespread and $\mathrm{N}$-tolerant monitor in the study area.

\section{Effects of agrochemicals on lichens}

The effects of agrochemicals upon lichens on fruit trees was the subject of two studies. The mapping study in St. Gallen showed no influence of agrochemicals on the lichen flora on pear $(n=120)$ and apple trees $(n=40)$. Apparently less chemical was used in this region. Differences between apple and pear trees (higher species number and more nitrophytic species on pear trees) seem to correlate with the surface texture of the substratum, since the bark pH of both trees do not differ (Meile 1993). Äberhardt (1985) compared the lichen cover and frequency of apple trees treated regularly with OleoDiazinon insecticide with trees untreated for 40 years (Fig. 5). Observations showed better vitality of lichens and higher species number on untreated trees. From a total of 12 species, Parmelia flaventior and Pseudevernia furfuracea were not found on treated trees. However these are preliminary observations and further detailed studies are required.

\section{Growth response of lichens in alpine grasslands to treatment with mineral nutrients}

The growth response of Cetraria islandica and Stereocaulon alpinum exposed in 32 OTCs in the Swiss Central Alps was independent of $\mathrm{CO}_{2}$ treatment. Cetraria islandica showed almost no growth and $S$. alpinum even regressed during a single vegetation period in the OTC. In freeland control plots, on the other hand, both species showed considerable growth within the same period. With regard to the poikilohydric structure of lichens, the responses observed 


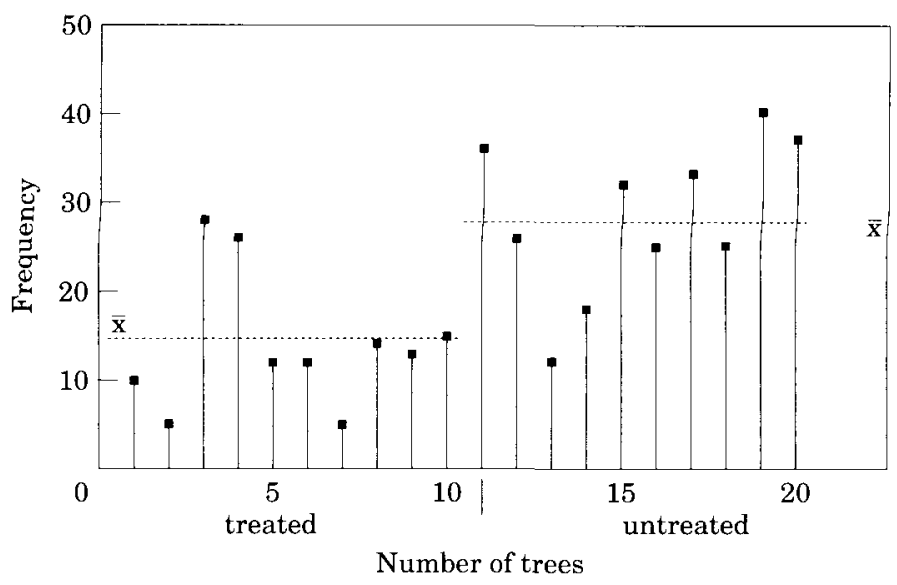

FIG. 5. Summation of frequency of lichens occurring on apple trees with and without insecticide treatment (according to Äberhardt 1985).

might be more closely tied to microclimatic factors (i.e. air flow, humidity) rather than to elevated $\left[\mathrm{CO}_{2}\right]$ (Ineichen 1994). In OTCs treated with mineral nutrients, the samples of $C$. islandica in plots with double $\left[\mathrm{CO}_{2}\right]$ increased in weight $(+0.75 \%$ p.a. $)$ whereas $S$. alpinum showed a decrease $(-0.72 \%$ p.a. $)$. In control OTCs $C$. islandica was nearly stable $(+0.3 \%$ p.a.) and $S$. alpinum decreased ( $-0.88 \%$ p.a.). Cetraria islandica, with the green alga Trebouxia as its photobiont, is more dependent on mineral nutrients than $S$. alpinum, which contains the cyanobacterium Nostoc along with Trebouxia (Ruoss \& Ineichen, unpublished data). The presence of cyanobacteria seems to reduce the impact of fertilizers and increased $\mathrm{CO}_{2}$.

\section{Discussion}

The results from the projects conducted within the NML lichen research programme show the need for further study on the effects of agriculture on lichens. Results and further observations showed the considerable influence of nutrients upon the lichen vegetation in lowland and mountain regions. The effects can occur by direct application of nutrients, as with farming, or indirectly through atmospheric depositions, especially near emission sources. They result in the following effects on lichens: changes in composition of lichen cover, species distribution patterns and pattern of colonization, damage, and increased uptake of nitrogen. Very little is known about the influence of such agrochemicals as herbicides and insecticides upon lichens.

Terricolous lichens are very sensitive to agricultural impacts such as grazing, trampling, traffic, and fertilization. They have therefore become rare in the rural areas of Central Switzerland (Ruoss \& Clerc 1987; Dussex \& Held 1990). The idea of using terricolous lichens (e.g. species of Cladonia, Cetraria islandica) in prealpine bogs as biomonitors could not be realized, although this 
seems to be possible in boreal areas such as Scotland, Scandinavia and the high Alps. The effects of nitrogen immissions on bog vegetation seem to be considerable. Studies in the prealpine areas of Bavaria showed comparable results (Melzer et al. 1992; Pohl 1991). Connected with the restoration of bogs and the extension of grazing and farming in prealpine and mountain areas, the re-establishment of former lichen-rich stands could be of general interest in monitoring studies. Mineral nutrients seem to be the limiting factor in alpine ecosystems. Additional field studies in undisturbed alpine ecosystems could give more information on the response of lichens to nutrients under natural conditions. This would become important information for studies on the effects of agriculture on terricolous lichens.

A correlation between $\mathrm{N}$ deposition and the total $\mathrm{N}$ content of lichens near emission sources was shown by analyses of Physcia caesia. Significant correlations between wet deposition of ammonia and the total $\mathrm{N}$ content of exposed Hypogymnia physodes were demonstrated in studies conducted by Metzger (1993).

In the area of Canton Lucerne, the $\mathrm{N}$ deposition showed a significant correlation with the intensity of agriculture (Amt für Umweltschutz 1993). Both $\mathrm{N}$ deposition rates and the $\mathrm{N}$ load in Switzerland were calculated by the Federal Office of Environment, Forests and Landscape (FOEFL). The $\mathrm{N}$ loads calculated from 1993-1995 were: for deciduous forest $43.3 \mathrm{~kg} \mathrm{ha}^{-1}$ year ${ }^{-1}$, species-rich grassland $29 \cdot 3 \mathrm{~kg} \mathrm{ha}^{-1}$ year $^{-1}$, alpine grassland $18 \mathrm{~kg}$ $\mathrm{ha}^{-1}$ year ${ }^{-1}$. The exceedance of critical load of $\mathrm{N}$ was $26 \mathrm{~kg} \mathrm{ha}^{-1}$ year $^{-1}$ in deciduous forests, $4 \cdot 3 \mathrm{~kg} \mathrm{ha}^{-1}$ year $^{-1}$ for species-rich grassland and $8.0 \mathrm{~kg}$ $\mathrm{ha}^{-1}$ year ${ }^{-1}$ for alpine grasslands. Nitrogen deposition was considered to be homogeneous over a large area of the Swiss Plateau, especially in the study area of the Canton Lucerne. Large-scale lichen monitoring studies with regard to agricultural effects would show the feasibility of using nitrophytic lichens as bioindicators of atmospheric nitrogen deposition. So far, preliminary results have shown how difficult it is to interpret the indication values of lichens and to correlate them with emission calculations, immission measurements and ecological factors. The interactive balance between decreasing acid pollutants and increasing $\mathrm{N}$ deposition along with ecological factors is very sensitive. Thus the re-establishment of lichens and the direction of such is unpredictable and difficult to explain.

The projects were conducted in association with the Department of Environment of Lucerne, the Botanical Institutes of the University of Bern, the Geographical Institute of the University of Zürich and the canton laboratory. The following collaborators contributed results to this paper: Andreas Burri, Andreas Graf, Nicola Dussex, Thomas Held, Ruth Ineichen, Christine Keller, Patrick Meile, Evelin Pfeifer, Corinna Walter. I am very grateful to Elizabeth Gosselin who patiently corrected the English.

\section{REFERENCES}

Äberhardt, S. (1985) Untersuchung der Flechtenflora an chemisch behandelten und unbehandelten Apfelbäumen. Semesterarbeit an der Ingenieurschule für Obst-, Wein- und Gartenbau. 1-15. Amt für Umweltschutz (1993) Stickstoffbilanz für den Kanton Luzern. Die Suche nach Quellen, Senken und Zusammenhängen. Bericht von Prisca Bucher. 1-95.

Braun-Blanquet, J. (1928) Pflanzensoziologie. Grundzüge der Vegetationskunde 1. Berlin. 
Bründler Rodriquez, B. (1997) Vegetationsentwicklung in voralpinen Hochmooren. Mitteilungen der Naturforschenden Gesellschaft Luzerm 35: 125-130.

Dussex, N. \& Held, T. (1990) Atmosphärischer Nährstoffeintrag in voralpine Hochmoore. DoppelLizentiatsarbeit am Systematisch-Geobotanischen Institut der Universität Bern. 1-160.

FOEFL (1996) Critical loads of nitrogen and their exceedances. Eutrophying atmospheric deposition. Federal Office of Environment, Forests and Landscape, Environmental Series 275: $1-74$.

Graf, A. (1998) Flechtenvegetation in Relation zur Stickstoffdeposition im Kanton Luzern. Diplomarbeit am Geographischen Institut der Universität Zürich. 1-95.

Ineichen, R. (1994) Auswirkungen von erhöhtem $\mathrm{CO}_{2}$-Gehalt der Atmosphäre auf Flechten in alpinen ökosystemen. Diplomarbeit am Geographischen Institut der Universität Zürich. 1-62.

Körner, C., Diemer, M., Schäppi, B., Niklaus, P. \& Arnone III, J. (1997) The responses of alpine grassland to four seasons of $\mathrm{CO}_{2}$ enrichment: a synthesis. Acta Ecologica 18(3): 165-175.

Meile, P. (1993) Immissionsökologische Untersuchungen mit Hilfe von Flechten an Hochstammobstbäumen in der Agglomeration St. Gallen. Diplomarbeit am Geographischen Institut der Universität Zürich. 1-80.

Melzer, A., Pohl, W., Hünerfeld, G. \& Pfleiderer, P. (1992) Nitratbelastung von Hochmooren. ökophysiologische Untersuchungen zur Nitratbelastbarkeit von Hochmooren. Umwelt und Entwicklung Bayern, Bayerisches Staatsministerium für Landesentwicklung und Umweltfragen. Materialien 81: 1-78.

Metzger, U. (1993) Stickstoffgehalt der im Winter 1991/92 exponierten Flechten in Relation zum Nitrat- und Ammoniumgehalt im Freilandniederschlag und statistische Interpretation der Beziehungen zwischen Flechtenparametern und Immissions-bzw. Klimavariablen. Gutachten im Auftrag der Senatsverwaltung für Stadtentwicklung und Umweltschutz. 1-56. Berlin.

Müller, A., Joller, T., Ruoss, E. \& Gallati, J. (1993) Klima und Luftqualität. Mitteilungen der Naturforschenden Gesellschafi Luzem 33: 399-414.

Pohl, W. (1991) Ökophysiologische Untersuchungen zum Stickstoffmetabolismus von HochmoorSphagnen. Diplomarbeit, Institut für Botanik und Mikrobiologie der Technischen Universität München. 1-66.

Ruoss, E. (1991) Flechtenreichtum-Spiegelbild des Naturraumpotentials. Mitteilungen der Naturforschenden Gesellschaft Luzerm 32: 197-214.

Ruoss, E. (1992) Flechten im Kanton Luzern. Untersuchungen zur Bioindikation und Floristik, sowie zur Immissionsökologie voralpiner Hochmoore. Veröffentlichung des Natur-Museums Luzern 3: 1-98.

Ruoss, E. \& Clerc, P. (1987) Bedrohte Flechtenrefugien im Alpenraum. Verhandlungen der Gesellschafı für ökologie. Band XV, Gfö Graz.

Ruoss, E. \& Keller, C. (1988) Flechtenuntersuchungen im Kanton Luzern. Teilprojekt A: Flechteninventar. 1. Zwischenbericht. 1-26.

Ruoss, E., Vonarburg, C. \& Joller, T. (1992) Möglichkeiten und Grenzen der Flechtenbioindikation bei der Bewertung der Umweltsituation in der Zentralschweiz. Bioindikation ein wirksames Instrument der Umweltkontrolle, VDI-Bericht $\mathrm{Nr}$. 901: 81-102.

Ugrinosits, M. (1980) Kjeldahl Stickstoffbestimmung mit verschiedenen Katalysatoren. Mitteilungen aus dem Gebiete der Lebensmitteluntersuchung und Hygiene 71: 124.

Vonarburg, C. (1993) Das Mikroklima an Standorten epiphytischer Flechten. Immissionsökologische Untersuchungen entlang eines Höhengradienten in den Zentralschweizer Voralpen. Veröffentlichungen aus dem Natur-Museum Luzern 5: 1-122.

Vonarburg, C., Ruoss, E. \& Burga, C. (1990) Flechten an Alleebäumen am Zürichsee. Vierteljahresschrift der Naturforschenden Gesellschaft Zürich 135/4: 239-258.

Walter, C. (1997) I licheni sul noce nel Mendrisiotto-Basso Ceresio. Un contributo sulla valutatione della Qualità dell' ambiente con l'utilizzo di bioindicatori. Lavoro di diploma nel Geographischen Institut der Universität Zürich. 1-71.

Wirth, V. (1972) Die Silikatflechten-Gemeinschaften im ausseralpinen Zentraleuropa. Dissertationes Botanicae 17: 1-303.

Wirth, V. (1991) Zeigerwerte von Flechten. Scripta Geobotanica 18: 215-237.

Wirth, V. (1995) Die Flechten Baden-Württembergs. 2nd Edn. Stuttgart: Ulmer. 
Downloaded from https:/www.cambridge.org/core. University of Basel Library, on 11 Jul 2017 at 09:10:06, subject to the Cambridge Core terms of use, available at https:/www.cambridge.org/core/terms. https://doi.org/10.1006/lich.1998.0175 